\title{
A sample holder for in-house X-ray powder diffraction studies of protein powders
}

\author{
Frankær, Christian Grundahl; Harris, Pernille; Ståhl, Kenny
}

Published in:

Journal of Applied Crystallography

Link to article, DOI:

$10.1107 /$ S0021889811039057

Publication date:

2011

Document Version

Publisher's PDF, also known as Version of record

Link back to DTU Orbit

Citation (APA):

Frankær, C. G., Harris, P., \& Ståhl, K. (2011). A sample holder for in-house X-ray powder diffraction studies of protein powders. Journal of Applied Crystallography, 44(6), 1288-1290.

https://doi.org/10.1107/S0021889811039057

\section{General rights}

Copyright and moral rights for the publications made accessible in the public portal are retained by the authors and/or other copyright owners and it is a condition of accessing publications that users recognise and abide by the legal requirements associated with these rights.

- Users may download and print one copy of any publication from the public portal for the purpose of private study or research.

- You may not further distribute the material or use it for any profit-making activity or commercial gain

- You may freely distribute the URL identifying the publication in the public portal

If you believe that this document breaches copyright please contact us providing details, and we will remove access to the work immediately and investigate your claim. 
Journal of

\section{Applied Crystallography}

ISSN 0021-8898

Received 5 July 2011

Accepted 22 September 2011

(C) 2011 International Union of Crystallography Printed in Singapore - all rights reserved

\section{A sample holder for in-house X-ray powder diffraction studies of protein powders}

\author{
Christian Grundahl Frankær, Pernille Harris and Kenny Ståhl*
}

Department of Chemistry, Technical University of Denmark, Kemitorvet 207, DK-2800 Kongens Lyngby, Denmark. Correspondence e-mail: kenny@kemi.dtu.dk

A sample holder for handling samples of protein for in-house X-ray powder diffraction (XRPD) analysis has been made and tested on lysozyme. The use of an integrated pinhole reduced the background, and good signal-to-noise ratios were obtained from only $7 \mu \mathrm{l}$ of sample, corresponding to approximately $2-3 \mathrm{mg}$ of dry protein. The sample holder is further adaptable to X-ray absorption spectroscopy (XAS) measurements. Both XRPD and XAS at the Zn $K$-edge were tested with hexameric $\mathrm{Zn}$ insulin.

\section{Introduction}

During the past decade, X-ray powder diffraction has proven itself able to solve and refine small protein structures from high-resolution powder data using synchrotron radiation (see e.g. Margiolaki \& Wright, 2008, and references therein). Powder diffraction patterns with well resolved peaks can also be obtained from highly optimized laboratory equipment (Margiolaki et al., 2007), but at the cost of longer data collection times. However, for a fast characterization and fingerprinting of protein crystal forms, X-ray powder diffraction (XRPD) can be carried out on widely used standard laboratory diffractometers (Hartmann et al., 2010, 2011). This 'rough' technique may be well suited for detection of substrate binding and verification of different protein conformations of already known systems (Norrman et al., 2006), and could thereby become a valuable complementary tool in the laboratory, as well as for product characterization in the pharmaceutical industry and enzyme production.

Metalloprotein structure determinations from single crystals are increasingly complemented by X-ray absorption spectroscopy (XAS). Quick in-house XRPD characterization of crystal forms before and after XAS measurements is indeed possible. In the present note the design of a sample holder for both in-house XRPD and $\mathrm{XAS}$ is described and tested on lysozyme and two conformations of hexameric $\mathrm{Zn}$ insulin, $\mathrm{T}_{6}$ and $\mathrm{R}_{6}$.

\section{Sample holder design}

The sample holder was developed for the Huber G670 diffractometer equipped with a flat powder specimen holder. The holder has been further improved from the holder used in the study by Hartmann et al. (2010) and is also adaptable for XAS experiments, as demonstrated by tests on hexameric $\mathrm{Zn}$ insulin. To collect as much signal as possible on the in-house X-ray sources, the general principle behind the design is to support a thin film of protein crystallites with a relatively large surface area. Rotation of the sample around an axis $\chi$ orthogonal to the detector is also important to avoid sedimentation on the windows and walls of the sample chamber and so to avoid multiple layers of powder. Schematic drawings and a photograph of the sample holder are shown in Fig. 1.

Figure 1
The sample holder consists of a $1.0 \mathrm{~mm}$-thick polycarbonate plate with a hole (either 4.5 or $3.0 \mathrm{~mm}$ in diameter, creating sample chamber volumes of 16 and $7 \mu \mathrm{l}$, respectively). Further dimensions are specified in Figs. $1(a)$ and $1(b)$. Metal-free polycarbonate was chosen to avoid a fluorescence signal from the sample holder, which for XAS experiments would conflict with the fluorescence signal from metalloproteins. Small holes have been drilled so that the holder fits the cryostat (Oxford Instruments, ITC503) available at the 8-11 XAS beamline at the synchrotron at MAX-lab, Lund, Sweden. The sample holder takes a small cylindrical volume of protein powder wetted by its mother liquor, and with a sample thickness of $1.0 \mathrm{~mm}$ this holder still allows the diffractometer to work in transmission mode. The

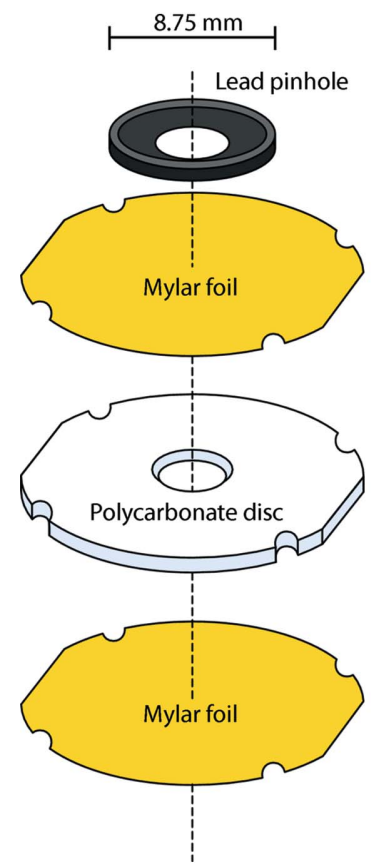

(a)

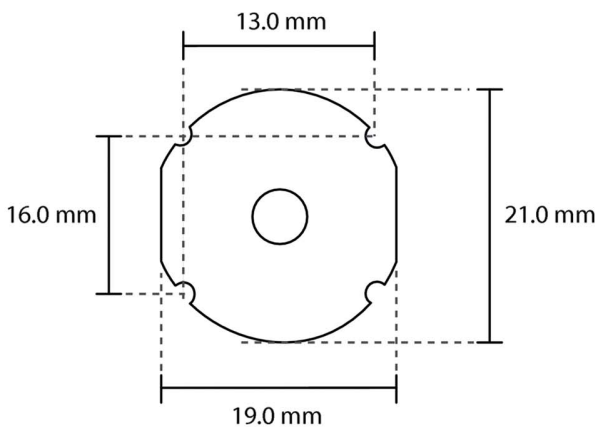

(b)

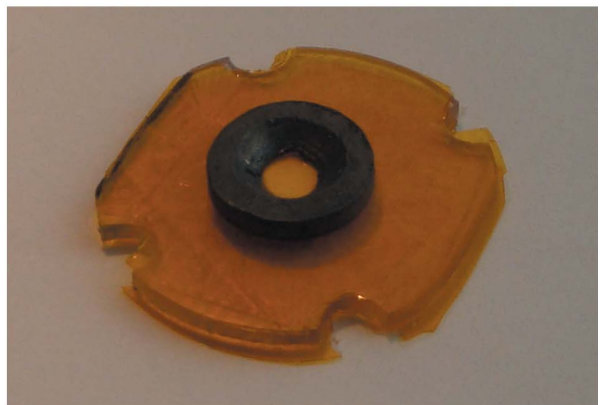

(c)

XRPD sample holder for the Huber G670 diffractometer. (a) Drawing of the individual parts of the unassembled sample holder. (b) Dimensions of the polycarbonate plate. (c) Photograph of the sample holder. 
sample is sealed by two pieces of mylar foil, which are attached to the polycarbonate plate with either epoxy glue or double-sided adhesive tape. For powder diffraction, a lead plate with a pinhole matching the diameter of the sample chamber is glued on top of the assembled holder and serves for efficient shielding of the background scattering. The inner edge profile of the lead plate has been cut at a $45^{\circ}$ angle to prevent shielding of the incoming X-ray beam. The pinhole plate fits exactly into the flat powder specimen holder at the Huber G670 diffractometer, allowing the sample to be centred in the beam. The relatively compact shape of the sample chamber eases mounting of the sample.

\section{Experimental}

The sample holder was tested on the Huber G670 diffractometer with protein powder of lysozyme from chicken egg white (Gallus gallus, 95\% Sigma Aldrich L-6876) and $\mathrm{Zn}$ insulin from bovine pancreas (Bos taurus, Sigma Aldrich I-5500). Tetragonal lysozyme crystals and trigonal $\mathrm{T}_{6}$ insulin crystals were grown according to the procedures described by Hartmann et al. (2010). $\mathrm{R}_{6}$ insulin crystals were grown with the phenol derivative $m$-cresol according to the procedure of Smith et al. (2000). The $\mathrm{T}_{6}$ and $\mathrm{R}_{6}$ insulin crystals were filtered using an Ultra-free-MC centrifuge filter (Amicon/Millipore) with a pore size of $0.22 \mu \mathrm{m}$, and excess zinc was eliminated by washing the crystals three times with a solution having a composition similar to the mother liquors except for containing zinc. Excess mother liquor was removed and the wetted crystals were gently crushed to a concentrated homogeneous suspension of protein powder.

The sample holders were loaded with the suspensions taking care that no air bubbles were trapped in the sample chambers when gluing the top foil in place. Rotation around $\chi$ was applied to the samples and data were collected on two lysozyme samples (16 and $7 \mu \mathrm{l}$, corresponding to approximately 5-6 and 2-3 mg of protein) for $4 \mathrm{~h}$ at room temperature using $\mathrm{Cu} K \alpha_{1}$ radiation $(\lambda=1.5406 \AA)$. The raw lysozyme powder diffraction patterns are compared in Fig. 2. For $\mathrm{Zn}$

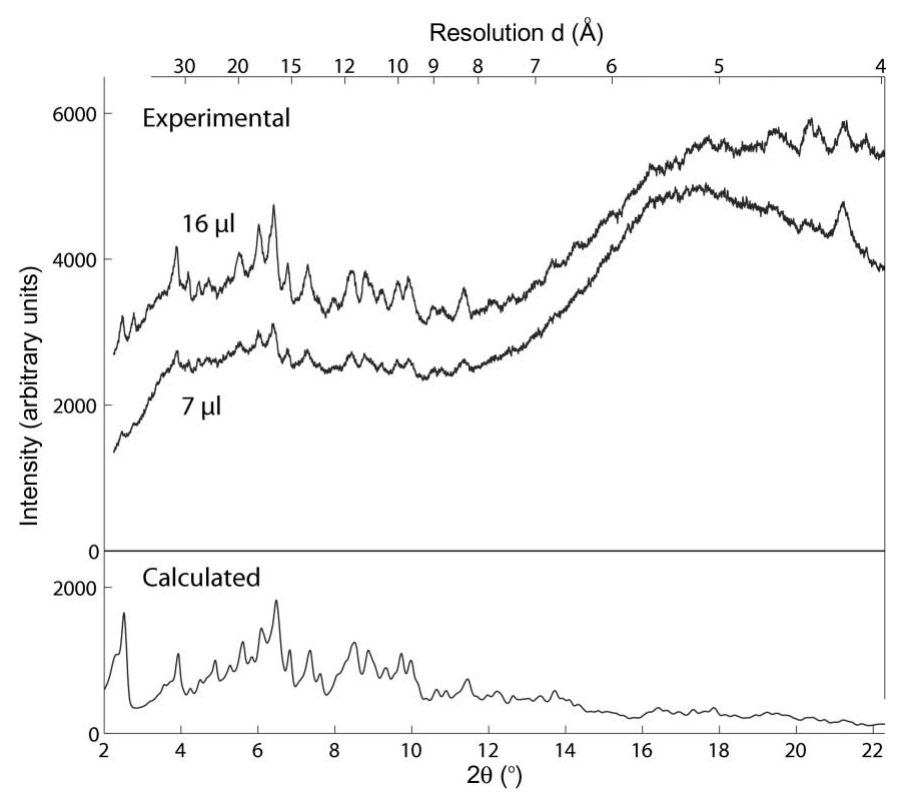

Figure 2

XRPD patterns of tetragonal crystals of hen egg white lysozyme prior to background subtraction. The data collection time was $4 \mathrm{~h}$ and $\mathrm{Cu} K \alpha_{1}$ radiation $(\lambda=$ $1.5406 \AA$ ) was used. A pattern calculated using optimized unit-cell and peak-shape parameters is shown for comparison (bottom). insulin, data were collected for $30 \mathrm{~min}$ on $7 \mu \mathrm{l}$ samples. The raw powder patterns are shown in Fig. 3, from which the crystal forms can be distinguished. For these systems, no radiation damage was observed.

An X-ray absorption spectrum was collected at the $\mathrm{Zn} K$-edge $(9659 \mathrm{eV})$ on the mounted insulin sample at the XAS beamline 8-11 at the synchrotron at MAX-lab, using an $\mathrm{Si}(111)$ double-crystal monochromator (Carlson et al., 2006). Fluorescence data were collected at $100 \mathrm{~K}$ with a passive implanted planar silicon detector as three scans of $60 \mathrm{~min}$, which were subsequently averaged. To check for occurrence of radiation damage the spectra were compared prior to averaging. No radiation damage was observed. The absorption spectra at the $\mathrm{Zn} K$-edge are shown in Fig. 4 . The extended X-ray

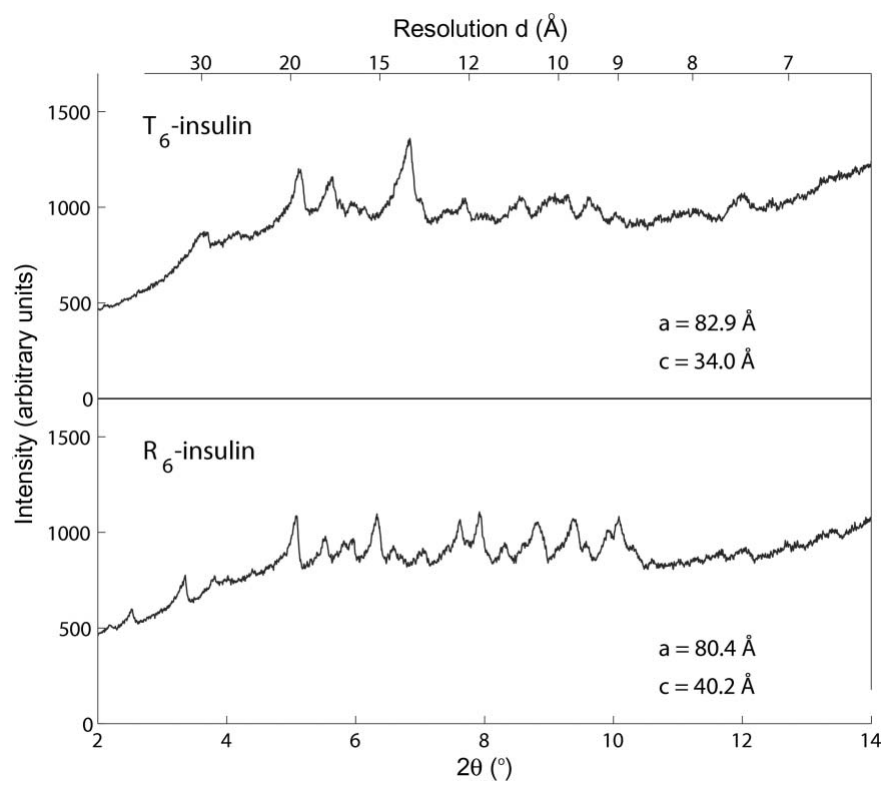

Figure 3

XRPD patterns of trigonal crystals of $T_{6}$ and $R_{6}$ insulin prior to background subtraction. Data were collected on $7 \mu \mathrm{l}$ of sample for $30 \mathrm{~min}$ using $\mathrm{Cu} K \alpha_{1}$ radiation $(\lambda=1.5406 \AA)$. Unit-cell parameters were optimized from a full pattern profile fit.
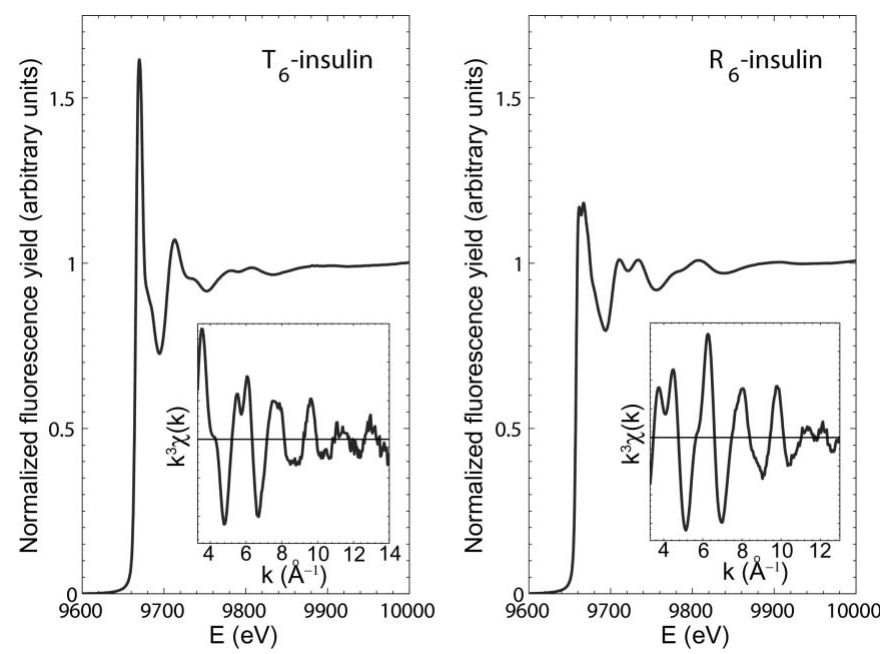

Figure 4

XAS spectra of hexameric $\mathrm{Zn}$ insulin collected at the $\mathrm{Zn} K$-edge with the combined XRPD and XAS sample holder. Insets: Extracted and $k^{3}$-weighted EXAFS spectra. Data with good signal-to-noise ratios were obtained to $13-14 \AA^{-1}$ in $k$-space. 
absorption fine structure (EXAFS) spectra were extracted using WinXAS (Ressler, 1998).

\section{Results}

The background intensity levels and the peak-to-noise ratios, $P / N$, which are interrelated, were estimated by looking at the raw lysozyme powder patterns presented in Fig. 2. Separating background from diffraction is, however, not straightforward because of the heavy peak overlap. The estimation of the background intensity was therefore done by scaling a calculated pattern to the experimental. Prior to the calculation of a powder pattern, unit-cell and peak-shape parameters were optimized using the procedure described by Hartmann et al. (2010). The background level, BG, was evaluated as a sum of intensities $I$ in the $2 \theta$ range $2-20^{\circ}$ by the following equation:

$$
\mathrm{BG}=\frac{\sum I_{\text {Background }}}{\sum\left(I_{\text {Bragg }}+I_{\text {Background }}\right)} 100 \%=\frac{\sum\left(I_{\text {Total }}-I_{\text {Bragg }}\right)}{\sum I_{\text {Total }}} 100 \%,
$$

where $I_{\text {Bragg }}$ was evaluated from a calculated pattern that was scaled to the experimental using PROTPOW (http://www.xray.kemi.dtu. $\mathrm{dk} /$ English/Computer Programs/PROTPOW.aspx). The background levels for lysozyme were 87.4 and $92.3 \%$ for the 16 and $7 \mu 1$ holders, respectively.

The $P / N$ ratios and the background levels depend on the collimation of the beam. Pinholes integrated into the design of the flat specimen sample holder ensure that the beam irradiates only the homogeneous part of the sample and thereby reduce the background, in particular at low $2 \theta$ angles. After an optimization of the beam stop position, it is possible to measure reflections down to $2.0^{\circ}$.

The adaptability of the sample holder was illustrated with insulin, where the same sample holder was used for XRPD and XAS. This ensures that both analyses are carried out on exactly the same sample, which reduces the amount of sample used and the preparation time. Both $T_{6}$ and $R_{6}$ insulin form trigonal crystals belonging to space group $R 3$, but with different $\mathrm{Zn}$ coordination and unit-cell parameters. As seen from the powder patterns in Fig. 3, the two crystal forms are clearly distinguishable, and the difference in $\mathrm{Zn}$ coordination is clearly evident from the absorption spectra shown in Fig. 4.

\section{Conclusions}

A sample holder for identification and fast characterization of protein crystal forms by XRPD using a standard laboratory source has been developed. Optimizing the collimation by pinholes, the design was improved to operate with sample volumes down to $7 \mu \mathrm{l}$, which is comparable to the performance of capillaries but the samples are easier to prepare. For metal-containing proteins the improved sample holder design was successfully applied to samples used for both powder diffraction and XAS experiments.

Special thanks to Katarina Norén for assistance at the XAS experiments. We acknowledge the workshop at DTU Chemistry for fabrication of the sample holders and Susanne Helmark for illustrations and the photograph.

\section{References}

Carlson, S., Clausén, M., Gridneva, L., Sommarin, B. \& Svensson, C. (2006). J. Synchrotron Rad. 13, 359-364.

Hartmann, C. G., Harris, P. \& Ståhl, K. (2011). Z. Kristallogr. Suppl. In the press.

Hartmann, C. G., Nielsen, O. F., Ståhl, K. \& Harris, P. (2010). J. Appl. Cryst. 43, $876-882$.

Margiolaki, I. \& Wright, J. P. (2008). Acta Cryst. A64, 169-180.

Margiolaki, I., Wright, J. P., Fitch, A. N., Fox, G. C., Labrador, A., Von Dreele, R. B., Miura, K., Gozzo, F., Schiltz, M., Besnard, C., Camus, F., Pattison, P., Beckers, D. \& Degen, T. (2007). Z. Kristallogr. Suppl. 26, 1-13.

Norrman, M., Ståhl, K., Schluckebier, G. \& Al-Karadaghi, S. (2006). J. Appl. Cryst. 39, 391-400.

Ressler, T. (1998). J. Synchrotron Rad. 5, 118-122.

Smith, G. D., Ciszak, E., Magrum, L. A., Pangborn, W. A. \& Blessing, R. H. (2000). Acta Cryst. D56, 1541-1548. 